\title{
Expression of paraoxonase types 1, 2 and 3 in reproductive tissues and activity of paraoxonase type 1 in the serum and seminal plasma of bulls
}

\author{
C. E. R. Ferreira ${ }^{1,2}$ | C. S. Haas $^{1,2}$ | K. L. Goularte ${ }^{1,2} \mid$ M. T. Rovani ${ }^{3}$ | F. F. Cardoso ${ }^{4}$ | \\ A. Schneider $^{3}$ | B. G. Gasperin ${ }^{1,2}$ | T. Lucia Jr ${ }^{1,2}$ (1)
}

${ }^{1}$ ReproPEI, Universidade Federal de Pelotas, Pelotas-RS, Brazil

${ }^{2}$ Faculdade de Veterinária, Universidade Federal de Pelotas, Pelotas-RS, Brazil

${ }^{3}$ Faculdade de Nutrição, Universidade Federal de Pelotas, Pelotas-RS, Brazil

${ }^{4}$ Embrapa Pecuária Sul, Bagé-RS, Brazil

\section{Correspondence}

Thomaz Lucia Jr, Universidade Federal de Pelotas, Faculdade de Veterinaria ReproPel Pelotas Rio Grande do Sul, Brazil.

Email: tluciajr@gmail.com

Funding information

This research was funded with a scholarship given to the first author by CAPES.

\begin{abstract}
Summary
The paraoxonases types 1, 2 and 3 (PON1, PON2 and PON3, respectively) are enzymes that degrade lipid peroxides, preventing oxidative damages relevant for male reproductive function. This study determined the expression of those three paraoxonases in reproductive tissues of bulls and evaluated correlations among the activity of PON1 in the serum and seminal plasma with breeding soundness parameters in bulls. The expression of PON1, PON2 and PON3 was characterised by RT-PCR in samples of testicular parenchyma, vesicular glands and epididymis collected from three slaughtered bulls. All three paraoxonases were expressed in the testicular parenchyma, PON2 and PON3 were both expressed in the epididymis head and PON3 was also expressed in the epididymis tail. The PON1 activity was determined in samples of serum and seminal plasma from 110 bulls submitted to breeding soundness evaluation. There was a strong correlation $(r=.90)$ between the activity of the PON1 in both serum and seminal plasma $(p<.0001)$. The PON1 activity in the seminal plasma was positively correlated with ejaculate's colour, sperm mass activity $(p=.04)$, motility, vigour and viability (all $p<.01$ ). Thus, PON1 may be a potential marker for sperm motility and viability in bulls.
\end{abstract}

KEYWORDS

acute phase proteins, bulls, reproductive tissues, sperm quality

\section{1 | INTRODUCTION}

The paraoxonases types 1, 2 and 3 (PON1, PON2 and PON3, respectively) are acute phase proteins capable to degrade lipid peroxides (Barranco, Roca et al., 2015), presenting antioxidant activity (Précourt et al., 2011). In rats, expression of PON1, PON2 and PON3 was reported in many tissues such as intestines, stomach, pancreas, hepatocytes, adipocytes, muscles, follicular fluid, seminiferous tubules and spermatozoa (Marsillach et al., 2008). The PON2 expression was detected in fewer tissues compared to PON1 and PON3, but it was already detected in the liver, lungs, placenta, heart and testicles of humans ( $\mathrm{Ng}$ et al., 2001).
The PON1 is involved in male reproductive functions, as it was identified in sperm lineage cells, Sertoli cells and Leydig cells of rats and humans (Marsillach et al., 2008, 2011). Low activity of PON1 was observed in the seminal plasma of infertile or subfertile men (Lazaros et al., 2011; Tavilani et al., 2014; Verit, Verit, Ciftci, Erel, \& Çelik, 2009) and in ejaculates of azoospermic men (Gulum et al., 2016). In boars, activity of PON1 was determined in the seminal plasma (Barranco, Roca et al., 2015), and its antioxidant activity was related to subsequent fertility in vivo (Barranco, Tvarijonaviciute et al., 2015). Such antioxidant activity would be beneficial for sperm quality and function as spermatozoa are sensitive to oxidative stress induced by increased production of reactive oxygen species (ROS) 
(Chatterjee \& Gagnon, 2001; Guthrie \& Welch, 2006), due to the lack of efficient antioxidant systems (Bucak, Atessahin, \& Yuce, 2008),

Potential antioxidant activity of PON1 was reported in bull semen (Dedeoglu, Arslan, \& Erzengin, 2014), but the presence of paraoxonases in reproductive tissues of bulls and associations among PON1 activity and reproductive traits were not determined yet. Nevertheless, at field level, potential bull fertility is most commonly estimated through breeding soundness evaluations, which includes conventional evaluations of semen quality (Kastelic \& Thundathil, 2008; Waldner, Kennedy, \& Palmer, 2010). However, after censoring bulls with obvious physical and reproductive flaws, ejaculates classified within generally recommended levels do not necessarily differentiate bulls with distinct fertility, which requires the evaluation of several parameters of sperm quality altogether (Gillan, Kroetsch, Maxwell, \& Evans, 2008; Puglisi et al., 2012). Thus, the search of potential marker capable to detect highly fertile individuals still needs to be developed. The objectives of this study were as follows: to determine the expression of PON1, PON2 and PON3 mRNA in the testicular parenchyma, epididymis and vesicular glands of bulls; and to evaluate PON1 activity in the serum and seminal plasma and potential correlations with breeding soundness parameters in bulls.

\section{2 | MATERIALS AND METHODS}

The procedures involving bulls were approved by the Ethics in Animal Experimentation Committee (CEEA-UFPel; process \# 1943).

\section{1 | Experiment 1}

Samples of testicular parenchyma, vesicular glands and of the head, body and tail of the epididymis were collected from three bulls in a local slaughterhouse. Such bulls were the only ones sent to slaughter during a 6-month period and had no defined racial and genetic pattern. The samples were immediately stored in 2-ml cryotubes into liquid nitrogen $\left(\mathrm{LN}_{2}\right)$.

To identify the gene expression of the paraoxonases, the total RNA of the collected tissues was extracted using TRIzol ${ }^{\circledR}$ (Invitrogen), following the manufacturer's recommendations. The extracted RNA was quantified by spectrophotometry (NanoDrop, Thermo Scientific; Abs 260/280 nm ratio). The purity of the RNA was evaluated through the absorption rate of the OD260/OD280 ratio, so values inferior to 1.8 were not used. The total RNA was treated with DNase (Promega) at $37^{\circ} \mathrm{C}$ for 5 min to digest any contaminant genomic DNA. After inactivation of the DNase at $65^{\circ} \mathrm{C}$ for $10 \mathrm{~min}$, the reverse transcriptase reaction was performed using the iScript cDNA Synthesis kit (Bio-Rad), as recommended by the manufacturer. Gene expression was conducted through real-time PCR (CFX384 real-time PCR; Bio-Rad) using SsoFast ${ }^{T M}$ EvaGreen ${ }^{\circledR}$ Supermix (Bio-Rad) and bovine-specific primers. The integrity of the cDNA samples was certified by amplification of the constitutive gene GAPDH. The primers used for the PON1, PON2 and PON3 genes (Table 1) were designed from sequences obtained in GenBank (NCBI) using the Primer-BLAST tool (http://www.ncbi.nlm.nih.gov/tools/primer-blast). Only samples that amplified the GAPDH gene were used to confirm the results. The specificity of the obtained amplicons was evaluated through analyses of dissociation curves (melting) and the size of the amplicons. For such procedure, $10 \mu \mathrm{l}$ of the PCR product of each gene was analysed by electrophoresis on a $2.0 \%$ agarose gel containing ethidium bromide, and the amplicon size was compared with a DNA ladder.

\subsection{Experiment 2}

This experiment included 110 Braford bulls with approximately 2 years of age, from seven farms located in the Rio Grande do Sul State, Brazil (29 $45^{\prime} 17^{\prime \prime} \mathrm{S}$ latitude and $57^{\circ} 05^{\prime} 18^{\prime \prime} \mathrm{W}$ longitude), all from the same breeding programme. Breeding soundness evaluations were conducted as described elsewhere (Kastelic \& Thundathil, 2008; Waldner et al., 2010). Body weight and scrotal circumference were determined for all bulls. Ejaculates were collected using a manually controlled electro-ejaculator (Palmer et al., 2005). The ejaculate volume $(\mathrm{ml})$ was recorded, and the ejaculate colour was classified through a score from 1 to 5 , in which 1 means clear and 5 means creamy (McGowan et al., 2002). Motility, vigour and mass activity were evaluated for fresh spermatozoa, at the time of breeding soundness evaluation, through optical microscopy. Sperm motility was evaluated under a $200 \times$ magnification, considering a scale of $0 \%-100 \%$. Sperm vigour was classified through a score from 1 to 5 , in which 1 means no progressive movement and 5 means maximum progressive movement. Sperm mass activity was classified through a score from 0 to 4 , in which 0 means no activity and 4 means rapid swirling activity (Fitzpatrick et al., 2002). Normal sperm morphology was determined

\begin{tabular}{|lllll|}
\hline Gene & \multicolumn{2}{c}{ Sequence } & Amplicon bp & Access number \\
\hline PON1 & F & ACTCCATTGAAGTCTCTGGACTG & 191 & NM_001046269.2 \\
& R & ACCACCGTAACTTTGGGTTCT & & \\
PON2 & F & TCTCTTTGTTGTAAACCACCCA & 148 & NM_001013588.1 \\
& R & ATGTTCTGGTCCAACAGCTATGA & & \\
PON3 & F & TGTTGATCCTGACACGGGAG & 122 & NM_001075479.1 \\
& R & CAGACAAAGCGTTCCGGATG & & NM_001034034.2 \\
GAPDH & F & GATTGTCAGCAATGCCTCCT & 94 & \\
\hline
\end{tabular}

TABLE 1 Initiators used for gene expression analyses-Experiment $1^{a}$

${ }^{\mathrm{a}} \mathrm{F}$, forward primer; $\mathrm{R}$, reverse primer. 
TAB LE 2 Descriptive statistics for parameters of breeding soundness evaluation for bulls-Experiment 2

\begin{tabular}{|lrrr|} 
Parameter & \multicolumn{1}{c}{$\boldsymbol{n}$} & Mean & \multicolumn{1}{c}{ SD } \\
\hline Ejaculate colour (1-5) & 95 & 2.8 & 1.0 \\
\hline Ejaculate volume (ml) & 95 & 2.8 & 2.5 \\
\hline Sperm mass activity (0-4) & 58 & 2.5 & 1.1 \\
\hline Sperm motility (\%) & 109 & 62.5 & 19.4 \\
\hline Sperm vigour (1-5) & 109 & 3.1 & 0.9 \\
\hline Sperm viability (\%) & 110 & 75.1 & 24.5 \\
\hline Sperm normal morphology (\%) & 110 & 84.8 & 13.8 \\
\hline Scrotal circumference (cm) & 110 & 37.6 & 3.1 \\
\hline Live weight (kg) & 95 & 601.0 & 64.8 \\
\hline
\end{tabular}

in samples extended in buffered formol saline (Fitzpatrick et al., 2002), and sperm viability was assessed in smears stained with eosin-nigrosin (Brito, Barth, Bilodeau-Goeseels, Panich, \& Kastelic, 2003), both through optical microscopy. Subsequently, semen samples were stored in $15-\mathrm{ml}$ conic tubes and centrifuged at $200 \times \mathrm{g}$ for $5 \mathrm{~min}$. The seminal plasma was fractioned in $1.5-\mathrm{ml}$ tubes and frozen in $\mathrm{LN}_{2}$.

At the time of the breeding soundness evaluations, blood samples were collected through puncture of the coccygeal vein using a $\mathrm{BD}$ Vacutainer ${ }^{\circledR}$ system with a $25 \times 8 \mathrm{~mm}$ needle. The blood was placed in sterile $10-\mathrm{ml}$ tubes with no anticoagulant. Blood samples were centrifuged at $1500 \mathrm{~g}$ for $10 \mathrm{~min}$. Serum samples were conditioned in $1.5-\mathrm{ml}$ cryotubes and frozen in $\mathrm{LN}_{2}$.

The PON1 arylesterase activity in serum and in seminal plasma was determined as described by Browne et al. (2007). Briefly, samples were diluted $1: 3$ in a $20 \mathrm{~mm}$ Tris/ $\mathrm{HCl}$ buffer solution $(1 \mathrm{~mm}$ $\mathrm{CaCl}_{2}$ ). Absorbance was measured at $270 \mathrm{~nm}$ through spectrophotometry (Cirrus 80ST), using $3.3 \mu \mathrm{l}$ of the diluted samples in $500 \mu \mathrm{l}$ of the buffer solution (containing $4 \mathrm{~mm}$ phenylacetate), for $60 \mathrm{~s}$. The PON1 activity, expressed in $\mathrm{U} / \mathrm{ml}$, was determined by the formula: $\Delta$ absorbance* $115^{*} 3$.

\section{3 | Statistical analyses}

Data were tested for normality using the Shapiro-Wilk test. Scrotal circumference was normally distributed, whereas the activity of
PON1 in seminal plasma and serum was normalised using logarithmic transformation. Correlations among such variables were determined by the Pearson's coefficient. As the remaining breeding soundness parameters were either categorical or not normally distributed, correlations involving such variables were determined by the Spearman's coefficient for nonparametric data. All analyses were conducted using Statistix ${ }^{\circledR}$ (2013).

\section{3 | RESULTS}

\section{1 | Experiment 1}

The three paraoxonases were expressed in the testicular parenchyma. Expression of PON2 and PON3 was also observed in the head of epididymis. The PON3 was also expressed in the tail of the epididymis. None of those three enzymes was expressed in the vesicular glands. The GAPDH gene was expressed in all samples of all bulls.

\subsection{Experiment 2}

The PON1 activity in the serum was $24.4 \pm 16.7 \mathrm{U} / \mathrm{ml}$, ranging from 2.2 to $80.7 \mathrm{U} / \mathrm{ml}$. In the seminal plasma, mean PON1 activity was $7.4 \pm 5.1 \mathrm{U} / \mathrm{ml}$, with values ranging from 0.9 to $27.1 \mathrm{U} / \mathrm{ml}$. The PON1 activity in serum was highly correlated $(r=.90)$ with the PON1 activity in the seminal plasma $(p<.0001)$.

The results of the breeding soundness evaluations are shown in Table 2. As shown in Table 3, the ejaculate volume was the only breeding soundness parameter positively correlated with the serum PON1 activity $(p<.05)$. However, PON1 activity in the seminal plasma was positively correlated with the ejaculate colour $(p<.01)$ and with sperm mass activity $(p=.04$ ), vigour and viability (all $p<.01$ ). Sperm motility was positively correlated $(p<.01)$ with PON1 activity in the seminal plasma (Figure 1), but uncorrelated with PON1 activity in the serum $(r=.13, p>.05)$.

\section{4 | DISCUSSION}

The expression of PON1, PON2 and PON3 in the testicular parenchyma and the PON1 activity in the seminal plasma and serum of bulls were characterised for the first time in this study. Expression of
TABLE 3 Correlations among the activity of the paraoxanse 1 (PON1) enzyme and parameters of breeding soundness evaluation for bulls-Experiment $2^{\mathrm{a}}$

\begin{tabular}{|c|c|c|c|c|c|}
\hline Parameter & $n$ & Serum PON1 & $p$ & $\begin{array}{l}\text { Seminal plasma } \\
\text { PON1 }\end{array}$ & $p$ \\
\hline Ejaculate colour (1-5) & 95 & -0.03 & .76 & 0.27 & $<.01$ \\
\hline Ejaculate volume (ml) & 95 & 0.20 & $<.05$ & 0.17 & .10 \\
\hline Sperm mass activity (0-4) & 58 & 0.10 & .46 & 0.27 & .04 \\
\hline Sperm vigour (1-5) & 109 & 0.03 & .78 & 0.28 & $<.01$ \\
\hline Sperm viability (\%) & 110 & 0.04 & .70 & 0.24 & $<.01$ \\
\hline Normal sperm morphology (\%) & 110 & -0.14 & .15 & -0.12 & .12 \\
\hline Scrotal circumference $(\mathrm{cm})$ & 110 & $-0.10^{\mathrm{a}}$ & .30 & $-0.03^{\mathrm{a}}$ & .76 \\
\hline Body live weight $(\mathrm{kg})^{\mathrm{a}}$ & 95 & -0.14 & .18 & -0.02 & .84 \\
\hline
\end{tabular}

aPearson's coefficient. All other correlations were determined using the Spearman's coefficient for nonparametric data. 


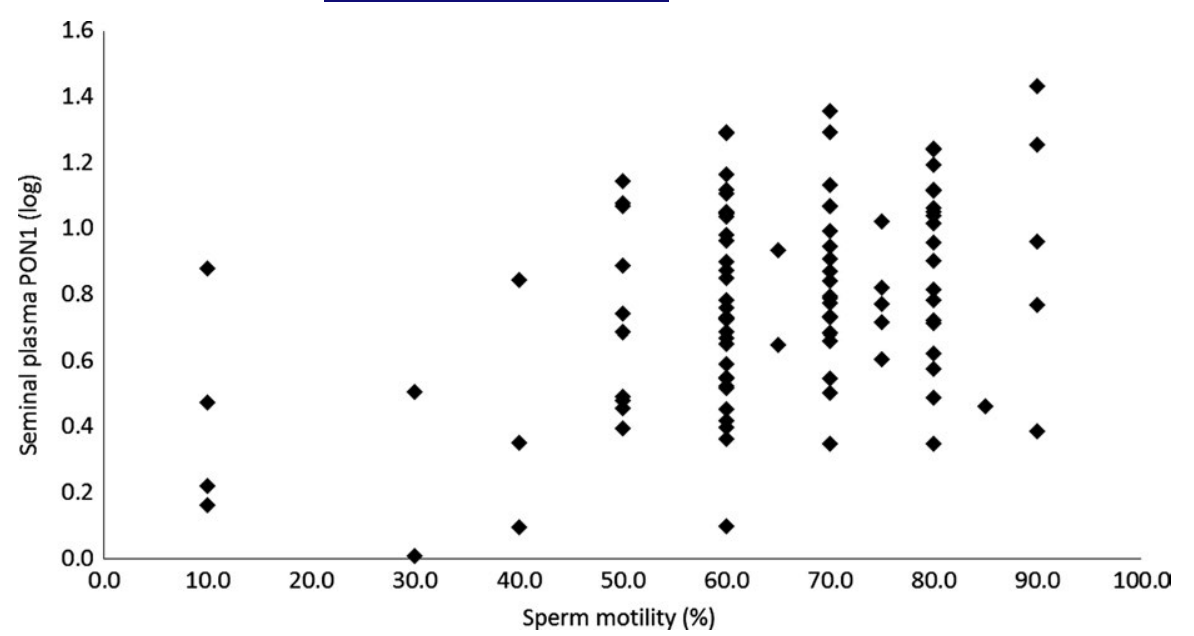

FIGURE 1 Correlation between the activity of the paraoxanse 1 (PON1) enzyme in the seminal plasma and sperm motility of bulls-Experiment $2^{*}$. ${ }^{*} r$ (Pearson's coefficient) $=0.38 ; p<.01$; $n=106$ those three enzymes has been previously reported in mice, not only in the testicular parenchyma, but also in Leydig cells and in germ cells (Marsillach et al., 2008). Furthermore, those three paraoxonases were also identified by immunohistochemistry in the testicular parenchyma of subfertile men (Marsillach et al., 2011), although their concentration in semen was reduced, likely due to cell catabolism. Additionally, PON2 and PON3 were both expressed in the head of the epididymis and PON3 was expressed in the tail of the epididymis. The PON2 was previously identified in the head and in the tail of boar spermatozoa with intact membranes (Barranco, Roca et al., 2015). Those findings indicate that three paraoxanases are present in bull testicles and may play a role in protecting spermatozoa against oxidative stress, at both intra- and extracellular levels.

Although PON1 activity was nearly three times greater in the serum than in the seminal plasma, the PON1 activity in the seminal plasma was correlated with a greater number of parameters of ejaculate and sperm quality compared to the serum PON1. The seminal plasma includes a variety of proteins originated from the testicles, epididymis and accessory sex glands, which are involved in processes such as sperm metabolism, maturation, capacitation, acrosome reaction and interaction with oocytes (Rodriguez-Martinez, Kvist, Ernerudh, Sanz, \& Calvete, 2011; Boe-Hansen et al., 2015; Rego et al., 2014). The fact that PON1 activity was observed in the seminal plasma of bulls (in the present study) and in the sperm-rich portion of boar's ejaculates (Barranco, Tvarijonaviciute et al., 2015) suggests that PON1 may be originated from either the testicles or the epididymis. Even though ejaculates of bulls do not have distinct portions, as occurs in boars, the positive correlation of the activity of serum PON1 with the ejaculate colour (a subjective indicator of sperm concentration) apparently corroborates the hypothesis of the testicular/epididymal origin of the seminal plasma PON1, which is to be confirmed by future research. An unbalanced activity of PON1 may result in oxidative stress at testicular level (Rego et al., 2014; Barranco, Roca et al., 2015). Therefore, excessive formation of ROS may occur, leading to damages in spermatozoa's membrane and DNA (Bucak et al., 2008). Such detrimental effects on spermatogenesis likely result in negative effects on seminal traits that are detectable in conventional breeding soundness evaluations
(Fitzpatrick et al., 2002). As suggested by our results, bulls with greater PON1 activity in the seminal plasma may present ejaculates with increased volume and improved sperm mass activity, motility, vigour and viability. Such traits are correlated among themselves and have moderate repeatability (Fitzpatrick et al., 2002), but, individually, their correlations with field fertility are commonly poor (Johnson, 1997), indicating that precise evaluations of fertility should be based on several combined assays (Kastelic \& Thundathil, 2008). Thus, although PON1 may qualify as a candidate marker for bull sperm quality, potential associations with subsequent fertility still require further investigation.

The expression of the three paraoxanases was confirmed in all samples by the amplification of the gene GAPDH, and the specificity of the amplified fragments was confirmed by both the size of the amplicons estimated through the comparison with the DNA marker and by the inexistence of unspecific bands. Distinct levels of enzymatic activity may be genetically driven by polymorphisms in the promoting and encoding regions of the PON1 gene, as observed in humans (Camps, Marsillach, \& Joven, 2009; Padungtod et al., 1999) and in cows (Silveira et al., 2015). The PON1 55M, PON1 192R and PON2 $311 \mathrm{C}$ alleles are associated with the activity of the PON1 and with increased levels of oxidative stress in men's seminal plasma (Lazaros et al., 2011). However, the presence and the activity of the PON2 and PON3 in the seminal plasma and in spermatozoa of bulls still need to be determined, as only the expression of the mRNA of such enzymes was investigated in the present study.

\section{5 | CONCLUSIONS}

The PON1, PON2 and PON3 were expressed in the testicular parenchyma of bulls. As the PON1 activity in the seminal plasma was positively correlated with some breeding soundness traits, PON1 may be a potential marker for bull sperm motility and viability.

\section{CONFLICT OF INTEREST}

The authors have no conflict of interest to declare. 


\section{ORCID}

\section{T. Lucia iD http://orcid.org/0000-0002-6609-7023}

\section{REFERENCES}

Barranco, I., Roca, J., Tvarijonaviciute, A., Ruber, M., Vicente-Carrillo, A., Atikuzzaman, M., ... Rodriguez-Martinez, H. (2015). Measurement of activity and concentration of paraoxonase $1(\mathrm{PON}-1)$ in seminal plasma and identification of PON-2 in the sperm of boar ejaculates. Molecular Reproduction and Development, 82, 58-65. https://doi.org/10.1002/ mrd.v82.1

Barranco, I., Tvarijonaviciute, A., Perez-Patiño, C., Alkmin, D. V., Ceron, J. J., Martinez, E. A., ... Roca, J. (2015). The activity of paraoxonase type 1 (PON-1) in boar seminal plasma and its relationship with sperm quality, functionality, and in vivo fertility. Andrology, 3, 315-320. https://doi. org/10.1111/andr.2015.3.issue-2

Boe-Hansen, G. B., Rego, J. P. A., Crisp, J. M., Moura, A. A., Nouwens, A. S., Li, Y., ... McGowan, M. R. (2015). Seminal plasma proteins and their relationship with percentage of morphologically normal sperm in 2-year-old Brahman (Bos indicus) bulls. Animal Reproduction Science, 162, 20-30. https://doi.org/10.1016/j.anireprosci.2015.09.003

Brito, L. F. C., Barth, A. D., Bilodeau-Goeseels, S., Panich, P. L., \& Kastelic, J. P. (2003). Comparison of methods to evaluate the plasmalemma of bovine sperm and their relationship with in vitro fertilization rate. Theriogenology, 60, 1539-1551. https://doi.org/10.1016/ S0093-691X(03)00174-2

Browne, R. W., Koury, S. T., Marion, S., Wilding, G., Muti, P., \& Trevisan, M. (2007). Accuracy and biological variation of human serum Paraoxonase 1 activity and polymorphism (Q192R) by kinetic enzyme assay. Clinical Chemistry, 53, 310-317.

Bucak, M. N., Atessahin, A., \& Yuce, A. (2008). Effect of anti-oxidants and oxidative stress parameters on ram semen after the freeze-thawing process. Small Ruminant Research, 75, 128-134. https://doi.org/10.1016/ j.smallrumres.2007.09.002

Camps, J., Marsillach, J., \& Joven, J. (2009). The paraoxonases: Role in human diseases and methodological difficulties in measurement. Critical Reviews in Clinical Laboratory Sciences, 46, 83-106. https://doi. org/10.1080/10408360802610878

Chatterjee, S., \& Gagnon, C. (2001). Production of reactive oxygen species by spermatozoa undergoing cooling, freezing, and thawing. Molecular Reproduction and Development, 59, 451-458. https://doi.org/10.1002/ (ISSN)1098-2795

Dedeoglu, N., Arslan, M., \& Erzengin, M. (2014). Purification of Holstein bull semen Paraoxonase 1 (PON1) by hydrophobic interaction chromatography and investigation of its inhibition kinetics by heavy metals. Biological Trace Element Research, 158, 29-35. https://doi.org/10.1007/ s12011-014-9916-8

Fitzpatrick, L. A., Fordyce, G., McGowan, M. R., Bertram, J. D., Doogane, V. J., de Faveri, J., ... Holroyd, R. G. (2002). Bull selection and use in northern Australia Part 2. Semen traits. Animal Reproduction Science, 71, 39-49. https://doi.org/10.1016/S0378-4320(02)00024-6

Gillan, L., Kroetsch, T., Maxwell, W. M. C., \& Evans, G. (2008). Assessment of in vitro sperm characteristics in relation to fertility in dairy bulls. Animal Reproduction Science, 103, 201-214. https://doi.org/10.1016/j. anireprosci.2006.12.010

Gulum, M., Gumus, K., Yeni, E., Dogantekin, E., Ciftci, H., Akin, Y., ... Altunkol, A. (2016). Blood and semen paraoxonase - arylesterase activities in normozoospermic and azoospermic men. Andrologia, 49(9), e12752. https://doi.org/10.1111/and.12752

Guthrie, H. D., \& Welch, G. R. (2006). Determination of intracellular reactive oxygen species and high mitochondrial membrane potential in Percoll-treated viable boar sperm using fluorescence-activated flow cytometry. Journal of Animal Science, 84, 2089-2100. https://doi.org/10.2527/jas.2005-766
Johnson, W. H. (1997). The significance to bull fertility of morphologically abnormal sperm. Veterinary Clinics of North America: Food Animal Practice, 13(2), 255-270. https://doi.org/10.1016/ s0749-0720(15)30339-x

Kastelic, J. P., \& Thundathil, J. C. (2008). Breeding soundness evaluation and semen analysis for predicting bull fertility. Reproduction in Domestic Animals, 43(Suppl. 2), 368-373. https://doi.org/10.1111/rda.2008.43. issue-s2

Lazaros, L. A., Xita, N. V., Hatzi, E. G., Kaponis, A. I., Stefos, T. J., Plachouras, N. I., ... Georgiou, I. A. (2011). Association of paraoxonase gene polymorphisms with sperm parameters. Journal of Andrology, 32, 394-401. https://doi.org/10.2164/jandrol.110.010348

Marsillach, J., Camps, J., Beltran-Debón, R., Rull, A., Aragones, G., MaestreMartínez, C., ... Mackness, B. (2011). Immunohistochemical analysis of paraoxonases-1 and 3 in human atheromatous plaques. European Journal of Clinical Investigation, 41, 308-314. https://doi.org/10.1111/ eci.2011.41.issue-3

Marsillach, J., Mackness, B., Mackness, M., Riu, F., Beltrán, R., Joven, J., \& Camps, J. (2008). Immunohistochemical analysis of paraoxonases-1, 2, and 3 expression in normal mouse tissues. Free Radical Biology \& Medicine, 45, 146-157. https://doi.org/10.1016/ j.freeradbiomed.2008.03.023

McGowan, M. R., Bertram, J. D., Fordyce, G., Fitzpatrick, L. A., Miller, R. G., Jayawardhana, G. A., ... Holroyd, R. G. (2002). Bull selection and use in northern Australia. 1. Physical traits. Animal Reproduction Science, 71, 25-37. https://doi.org/10.1016/S0378-4320(02)00023-4

Ng, C. J., Wadleigh, D. J., Gangopadhyay, A., Hama, S., Grijalva, V. R., Navab, M., ... Reddy, S. T. (2001). Paraoxonase-2 Is a ubiquitously expressed protein with antioxidant properties and is capable of preventing cellmediated oxidative modification of low density lipoprotein. Journal of Biological Chemistry, 276, 44444-44449. https://doi.org/10.1074/jbc. M105660200

Padungtod, C., Niu, T., Wang, Z., Savitz, D. A., Christiani, D. C., Ryan, L. M., \& $\mathrm{Xu}, \mathrm{X}$. (1999). Paraoxonase polymorphism and its effect on male reproductive outcomes among Chinese pesticide factory workers. American Journal of Industrial Medicine, 36, 379-387. https://doi.org/10.1002/ (ISSN)1097-0274

Palmer, C. W., Brito, L. F. C., Arteaga, A. A., Soderquist, L., Persson, Y., \& Barth, A. D. (2005). Comparison of electroejaculation and transrectal massage for semen collection in range and yearling feedlot beef bulls. Animal Reproduction Science, 87, 25-31. https://doi.org/10.1016/ j.anireprosci.2004.09.004

Précourt, L. P., Amre, D., Denis, M. C., Lavoie, J. C., Delvin, E., Seidman, E., \& Levy, E. (2011). The three-gene paraoxonase family: Physiologic roles, actions and regulation. Atherosclerosis, 214, 20-36. https://doi. org/10.1016/j.atherosclerosis.2010.08.076

Puglisi, R., Pozzi, A., Foglio, L., Spano, M., Eleuteri, P., Grollino, M. G., ... Gall, A. (2012). The usefulness of combining traditional sperm assessments with in vitro heterospermic insemination to identify bulls of low fertility as estimated in vivo. Animal Reproduction Science, 132, 17-28. https:// doi.org/10.1016/j.anireprosci.2012.04.006

Rego, J .P. A., Crisp, J. M., Moura, A. A., Nouwens, A. S., Li, Y., Venus, B., ... McGowan, M. R. (2014). Seminal plasma proteome of electroejaculated Bos indicus bulls. Animal Reproduction Science, 148, 1-17. https://doi. org/10.1016/j.anireprosci.2014.04.016

Rodriguez-Martinez, H., Kvist, U., Ernerudh, J., Sanz, L., \& Calvete, J. J. (2011). Seminal plasma proteins: What role do they play? American Journal of Reproductive Immunology, 66, 11-22. https://doi. org/10.1111/aji.2011.66.issue-s1

Silveira, P. A. S., Schwegler, E., Montagner, A., Krause, A. R. T., Acosta, D. A. V., Halfen, J., ... Schneider, A. (2015). Characterization of single nucleotide polymorphisms in the promoter region of the bovine paraoxonase 1 (PON1) gene affecting serum enzyme activity in dairy cows. The Veterinary Journal, 205, 101-103. https://doi.org/10.1016/ j.tvjl.2015.04.028 
Tavilani, H., Fattahi, A., Esfahani, M., Khodadadi, I., Karimi, K., Bahrayni, E., ... Latifi, Z. (2014). Genotype and phenotype frequencies of paraoxonase 1 in fertile and infertile men. Systems Biology in Reproductive Medicine, 60, 361-366. https://doi.org/10.3109/19396368.2014.960 624

Verit, F. F., Verit, A., Ciftci, H., Erel, O., \& Çelik, H. C. (2009). Paraoxonase-1 activity in subfertile men and relationship to sperm parameters. Journal of Andrology, 30, 183-189.

Waldner, C. L., Kennedy, R. I., \& Palmer, C. W. (2010). A description of the findings from bull breeding soundness evaluations and their association with pregnancy outcomes in a study of western Canadian beef herds. Theriogenology, 74, 871-883. https://doi.org/10.1016/ j.theriogenology.2010.04.012

How to cite this article: Ferreira CER, Haas CS, Goularte KL, et al. Expression of paraoxonase types 1, 2 and 3 in reproductive tissues and activity of paraoxonase type 1 in the serum and seminal plasma of bulls. Andrologia.

2018;50:e12923. https://doi.org/10.1111/and.12923 